\title{
STRATEGY TO CONSERVE MAXIMUM BIODIVERSITY OF LIMESTONE FLORA IN PENINSULAR MALAYSIA
}

\author{
Rafidah Abdul Rahman ${ }^{1}$ \& Ruth Kiew ${ }^{2}$
}

\begin{abstract}
The need to exploit limestone products for national development impacts on the conservation of rare and endangered limestone species. To minimise this impact it is necessary to identify which of the 570 limestone outcrops have high conservation importance and whether they have narrowly endemic and/or endangered limestone species. In the absence of detailed checklists for each outcrop, the Gesneriaceae is selected as being biodiverse on limestone, being well collected and outstanding in the number of endemic species and/or species restricted to limestone for mapping. Of the 210 species in the 25 genera of Gesneriaceae in Peninsular Malaysia, 42 species belonging to the genera Damrongia Kerr ex Craib, Emarhendia Kiew, A.Weber \& B.L.Burtt, Epithema Blume, Microchirita (C.B.Clarke) Yin Z.Wang, Monophyllaea R.Br., Ornithoboea Parish ex C.B.Clarke, Paraboea (C.B.Clarke) Ridl., Senyumia Kiew, A.Weber \& B.L.Burtt and Spelaeanthus Kiew, A.Weber \& B.L.Burtt grow on limestone hills. Of these 42 species, 28 are endemic and 16 are restricted to a single or adjacent hills. Mapping their distribution shows that in common with other families there are three distinct phytogeographical provinces (the Northern Province, Perak Province and the Asian Intrusion) but that the narrowly endemic species do not cluster on particular hills, nor does their distribution coincide with those of other narrowly endemic species in other families. This illustrates that a network comprising a large number of hills, not only those within the three provinces but also all those harbouring narrowly endemic species that are at risk of extinction if not conserved, is necessary to maximise conservation of the biodiversity of the limestone flora.
\end{abstract}

\section{INTRODUCTION}

There is an urgent need to reassess the current status of all limestone karst hills, particularly in relation to their sensitive plant and animal biodiversity to ascertain the impacts of various threats and uses. The ultimate goal is to conserve and totally protect as much biodiversity as we can but it is impossible to protect all the hills. Therefore we need to know how many species there are, where they occur and whether they are threatened. In particular we need to identify the hills with rich biodiversity including rare, narrowly endemic, obligate calciphiles and endangered plant species in order to conserve the maximum number of species of conservation importance.

1. Rafidah Abdul Rahman is a Researcher at the Forest Research Institute Malaysia (FRIM).

Address: Forest Research Institute Malaysia, 52109 Kepong, Selangor, Malaysia.

Email: rafidahar@frim.gov.my

2. Ruth Kiew is a Researcher at the Forest Research Institute Malaysia (FRIM).

Address: as above. 


\section{Plant diversity}

The limestone karst is a unique formation in Malaysia and comprises many species of flora that are not found in other non-limestone habitats. In Peninsular Malaysia, limestone hills occupy less than $0.4 \%$ of the land area, but their flora is disproportionately rich with about 1,600 species, representing around $19 \%$ of the Peninsula's total vascular flora of around 8,500 species (Kiew et al., 2010). The flora is also of great conservation importance, not only because of its species richness but also for its high level of endemism and large number of species restricted to living on limestone. Chin (1977) calculated that $21.4 \%$ of its species are endemic to Peninsular Malaysia and 257 species are restricted to living on limestone. Compared with other countries in SE Asia, the limestone flora of Peninsular Malaysia is well known thanks to two checklists (Henderson, 1939; Chin, 1977) and more recent intensive surveys of karst limestone in national parks and states (Taman Negara by Kiew (1985), Perak by Davison (1991), Kelantan by Davison \& Kiew (1990) and Perlis by Kiew (1993)).

\section{Threats}

The limestone flora in Peninsular Malaysia is particularly vulnerable and is one of the most threatened vegetation types (Saw et al., 2009) due to a combination of lack of legal protection and threats from quarrying, burning associated with agriculture, use as cave temples, and for eco-recreation and resort development (Kiew, 1997). Of the 570 limestone outcrops in Peninsular Malaysia (Price, 2014), only a few hills lie in protected areas such as national parks, GeoPark state parks, wildlife sanctuaries or within permanent reserved forests. The majority are unprotected on state land where quarrying takes precedence over other land uses. While cement and other limestone products are necessary for economic development there needs to be longer-term planning in the use of this non-renewable resource which also takes into account biodiversity and its many other values. These other values include cultural values such as karst limestone houses and cave temples, aesthetic values as they form majestic landscape features, recreational values for eco-recreation, archaeological values as their geological features, such as caves, have been found to be major archaeological sites, and biological values for their fauna, fossils and flora. As a non-renewable resource, it requires wise utilisation and orderly development so as to prevent undue waste and permanent damage. The abundant supply of below-ground limestone should be developed in preference to the blasting of the iconic karst hills (Davison, 1991).

\section{Protection}

Karst limestone is recognised at the federal level as an Environmentally Sensitive Area but this has yet to be translated on the ground into legal protection at the state level. Similarly, while the protection of 50\% of Important Plant Areas (IPAs) is a target in the 
Malaysia National Strategy for Plant Conservation (Saw et al., 2009), the mechanism for getting legal protection for IPAs has not yet been enacted. Many, if not most, limestone hills would qualify as IPAs because they are home to narrowly endemic species.

\section{Situation}

Recognising that not every hill can be conserved, the dilemma then is which hills to recommend for legal protection and which can be exploited for their commercial value. The problem is that very few hills (only three or four) have been the subject of detailed surveys, and the results of these are rather unexpected in that no single hill harbours more than a fraction (about 20\%) of the total limestone flora. The checklist of Bukit Takun includes 225 species (Chia, 1983), Batu Caves includes 270 species (Kiew, 2014) and Gunung Kanthan includes 220 species (Kiew et al., 2014). In addition, each hill has a different assemblage of species. It appears that widespread species are the exception rather than the rule. This means that in order to make a sound recommendation on which hills are to be conserved, each and every hill needs to be surveyed in detail. Surveying hills, however, is time consuming. Since producing a list of the most important hills to be conserved is a matter of urgency in the face of the increasing number of quarrying licences being issued, can a well-collected plant group be used to identify important plant areas?

The Gesneriaceae family is outstanding for the number of taxa because (1) it is one of the best-represented families on limestone ( 42 species), making up $16 \%$ of those species restricted to the limestone (Table 1); and (2) it includes both widespread species and 14 narrowly endemic species, i.e. restricted to a single hill or adjacent hills (Table 2). The family has been the focus of several botanical studies so the distribution of its species is relatively well known; of particular importance is the distribution of narrowly endemic species (Table 3).

\section{METHOD}

Using the Gesneriaceae as a case study, the distribution of species was mapped to determine (1) which hills are particularly biodiverse; (2) whether there are patterns of distribution and, if so, whether they reflect distribution of limestone species in general; and (3) which hills harbour narrowly endemic species.

\section{RESULTS}

\section{Biodiverse hills}

In general, large hills often comprise many microhabitats that support a wealth of Gesneriaceae from those that grow on limestone-derived soil surrounding the base of the hill (Monophyllaea horsfieldii R.Br., shaded, damp limestone rocks at the base (species 


\begin{tabular}{|l|l|l|l|}
\hline \multicolumn{1}{|c|}{ Genus } & Total no. of species & $\begin{array}{c}\text { No. of species restricted } \\
\text { to limestone }\end{array}$ & $\begin{array}{c}\text { No. endemic in } \\
\text { Peninsular Malaysia }\end{array}$ \\
\hline Damrongia & 1 & 1 & 0 \\
\hline Emarhendia & 1 & 1 & 1 \\
\hline Epithema & 3 & 2 & 2 \\
\hline Microchirita & 6 & 6 & 4 \\
\hline Monophyllaea & 6 & 5 & 5 \\
\hline Ornithoboea & 1 & 1 & 0 \\
\hline Paraboea & 22 & 22 & 14 \\
\hline Senyumia & 1 & 1 & 1 \\
\hline Spelaeanthus & 1 & 1 & 28 \\
\hline Total & 42 & 40 & 1 \\
\hline
\end{tabular}

Table 1 Genera and species of Gesneriaceae that occur in limestone hills, the number restricted to limestone and endemic in Peninsular Malaysia.

\begin{tabular}{|l|l|l|l|l|}
\hline \multicolumn{1}{|c|}{ Genus } & Northern Province & Perak Province & Asian Intrusion & Widespread \\
\hline Damrongia & 0 & 0 & 1 & 0 \\
\hline Emarhendia & 0 & 0 & 1 & 0 \\
\hline Epithema & 0 & 1 & 1 & 1 \\
\hline Microchirita & 1 & 2 & 2 & 1 \\
\hline Monophyllaea & 1 & 2 & 1 & 2 \\
\hline Ornithoboea & 1 & 0 & 0 & 0 \\
\hline Paraboea & 11 & 4 & 5 & 2 \\
\hline Senyumia & 0 & 0 & 1 & 0 \\
\hline Spelaeanthus & 0 & 0 & 1 & 0 \\
\hline
\end{tabular}

Table 2 Distribution patterns in species of Gesneriaceae on limestone in Peninsular Malaysia.

of Epithema, Microchirita, Monophyllaea and rosette Paraboea) to the robust Paraboea species (often more than one) on the exposed summit. However, the assemblage of these species varies between hills. For example, Batu Caves is home to Epithema parvibracteatum, Microchirita caliginosa (C.B.Clarke) Yin Z.Wang, Monophyllaea hirticalyx Franch. and M. horsfieldii, Paraboea paniculata (Ridl.) B.L.Burtt and Paraboea verticillata (Ridl.) B.L.Burtt, while on Gunung Kanthan grow Epithema saxatile Blume, Microchirita caliginosa and M. sericea (Ridl.) A.Weber \& Rafidah, Monophyllaea hirticalyx and $M$. horsfieldii, Paraboea capitata Ridl. var. capitata, $P$. paniculata and $P$. vulpina Ridl. 


\begin{tabular}{|c|c|c|c|c|c|c|c|c|c|c|c|c|c|c|c|c|}
\hline & 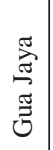 & 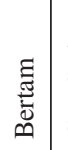 & $\begin{array}{l}\text { 壳 } \\
\omega \\
\widetilde{J} \\
\tilde{J}\end{array}$ & & & & & & & & & & & & & \\
\hline 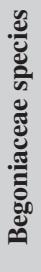 & 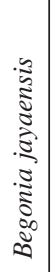 & 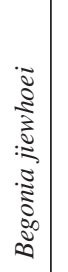 & 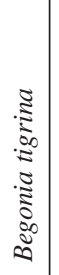 & & & & & & & & & & & & & \\
\hline 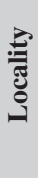 & 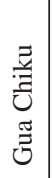 & 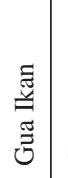 & 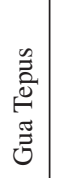 & 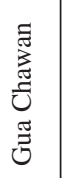 & & & & & & & & & & & & \\
\hline 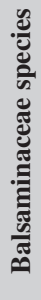 & 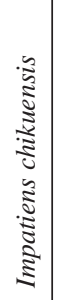 & 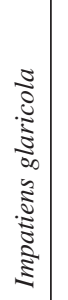 & 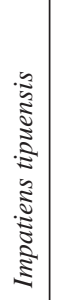 & 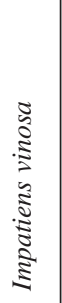 & & & & & & & & & & & & \\
\hline 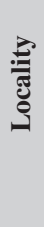 & 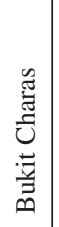 & 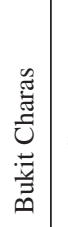 & 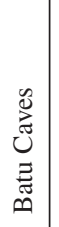 & 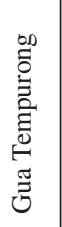 & 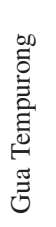 & 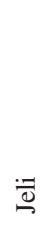 & 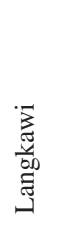 & 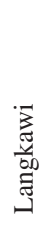 & 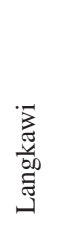 & 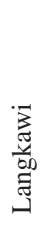 & 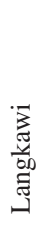 & 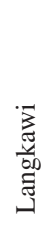 & 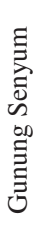 & 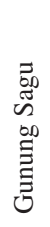 & 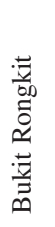 & 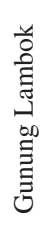 \\
\hline 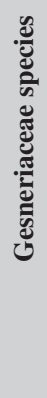 & 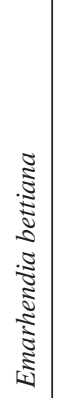 & 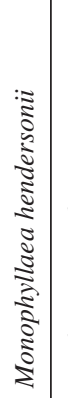 & 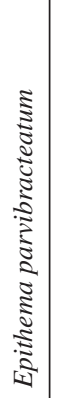 & 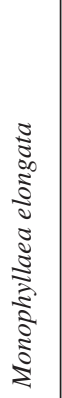 & 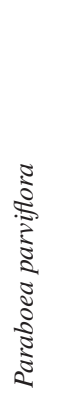 & 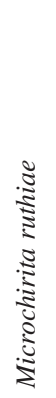 & 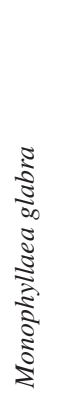 & 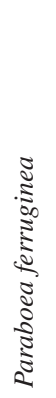 & 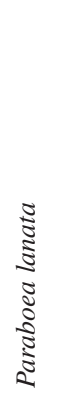 & 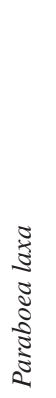 & 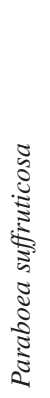 & 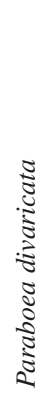 & 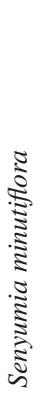 & 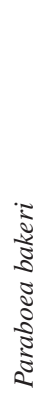 & 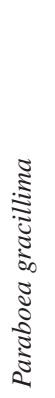 & 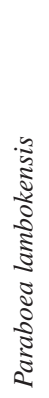 \\
\hline
\end{tabular}


Mapping of species illustrates that very few (seven out of 45) are widespread, with most species falling within three distinct provinces.

(a) The Northern Province (Whitmore, 1975) located north of a line from Kangar to Pattani where species have more in common with the flora of peninsular Thailand than with the rest of Peninsular Malaysia, e.g. Microchirita rupestris (Ridl.) A.Weber \& Rafidah and Ornithoboea flexuosa (Ridl.) B.L.Burtt (Rafidah et al., 2009) (Fig. 1). This province experiences a distinct dry season unlike the ever-wet equatorial climate to the south.

(b) The Perak Province (Ashton, 1992), which includes Perak and Selangor, e.g. Microchirita caliginosa, Paraboea paniculata and Epithema parvibracteatum (Fig. 2) on the west coast of the Peninsula.

Fig. 1 Distribution of Ornithoboea flexuosa indicated by red dots. The green dots indicate all the limestone hills in Peninsular Malaysia.

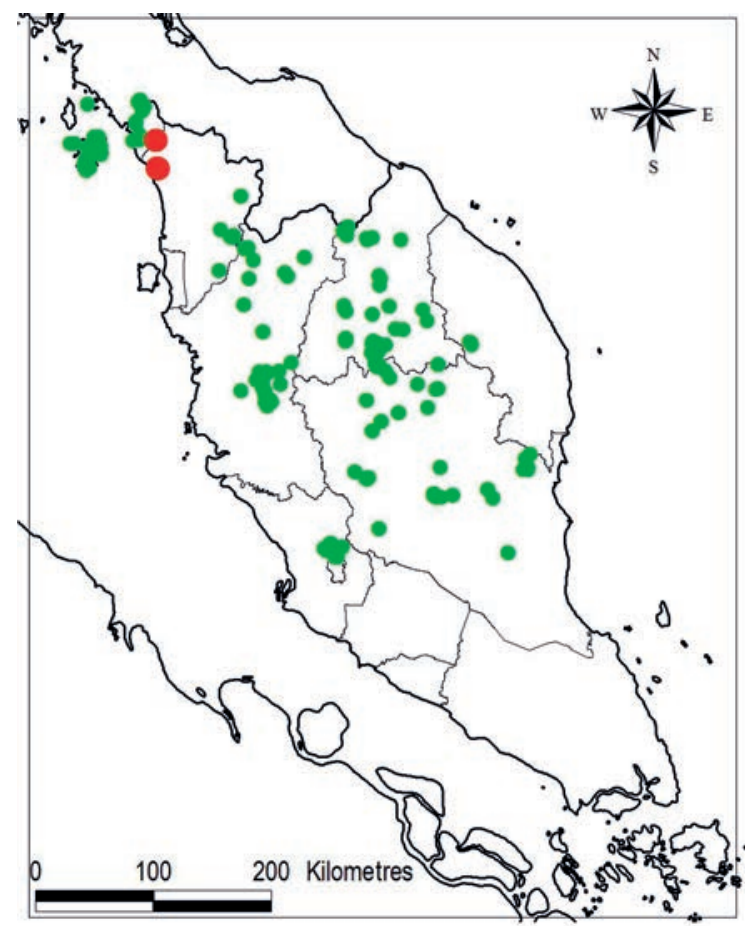


Fig. 2 Distribution of Epithema parvibracteatum indicated by red dots. The green dots indicate all the limestone hills in Peninsular Malaysia.

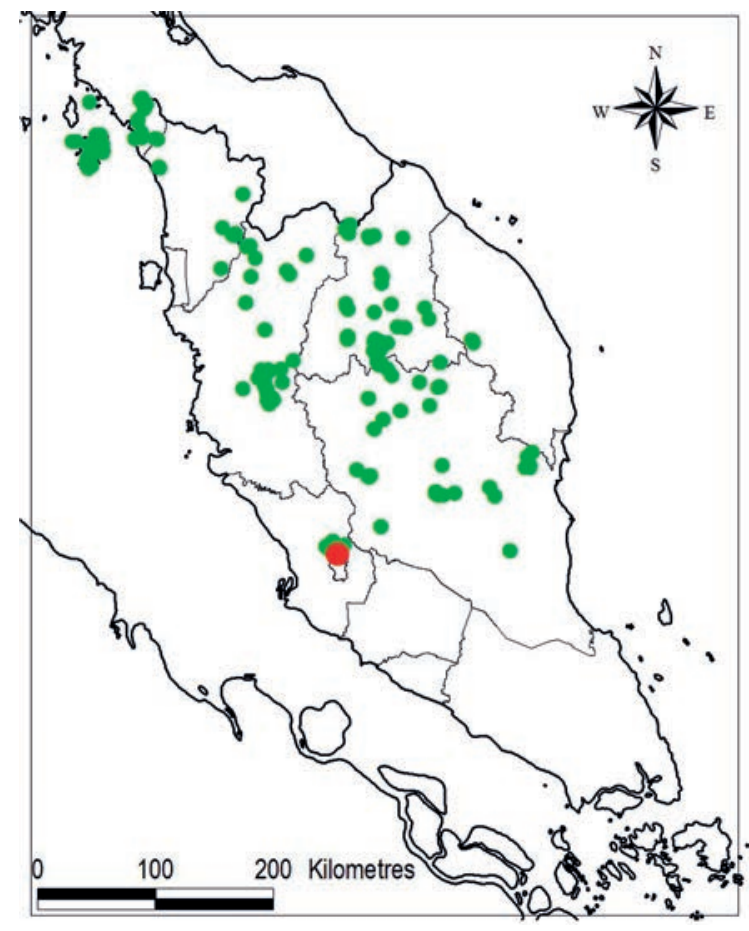

(c) The Asian Intrusion (Corner, 1960), stretching from northern Kelantan south to Pahang. Microchirita involucrata (Craib) Yin Z.Wang and Spelaeanthus chinii Kiew, A.Weber \& B.L.Burtt (Rafidah et al., 2010) (Fig. 3) belong in the province.

These patterns are seen in other speciose groups restricted to limestone such as the balsams (Kiew, 1991) and begonias (Kiew, 2005) and also by the general lowland non-limestone flora (Wong, 1998). To capture maximum biodiversity, it is therefore necessary to have a network of hills including representatives from all three provinces.

Sixteen species of Gesneriaceae are narrow endemics (Table 3) and are confined to a single hill or a group of adjacent hills. Apart from Langkawi, which is a biodiversity hotspot for limestone gesneriads, Table 3 illustrates that a significant number of species are narrowly endemic but that they do not cluster on particular hills. This is in fact a common feature of the limestone flora and is seen in other families, such as Balsaminaceae (Kiew, 1991) and Begoniaceae (Kiew, 2005). This clearly illustrates that to conserve maximum diversity and to prevent the extinction of these narrowly endemic species a large number of hills needs to be conserved. Already, there is a case of extinction in the wild as a direct consequence of quarrying activities for Paraboea bakeri because Bukit Sagu and the small adjacent hill, Bukit Tenggek, are both actively being quarried and have exterminated its populations. Fortunately, we were able to rescue a few plants that are now growing in tissue culture (Rafidah \& Tan, 2012). 


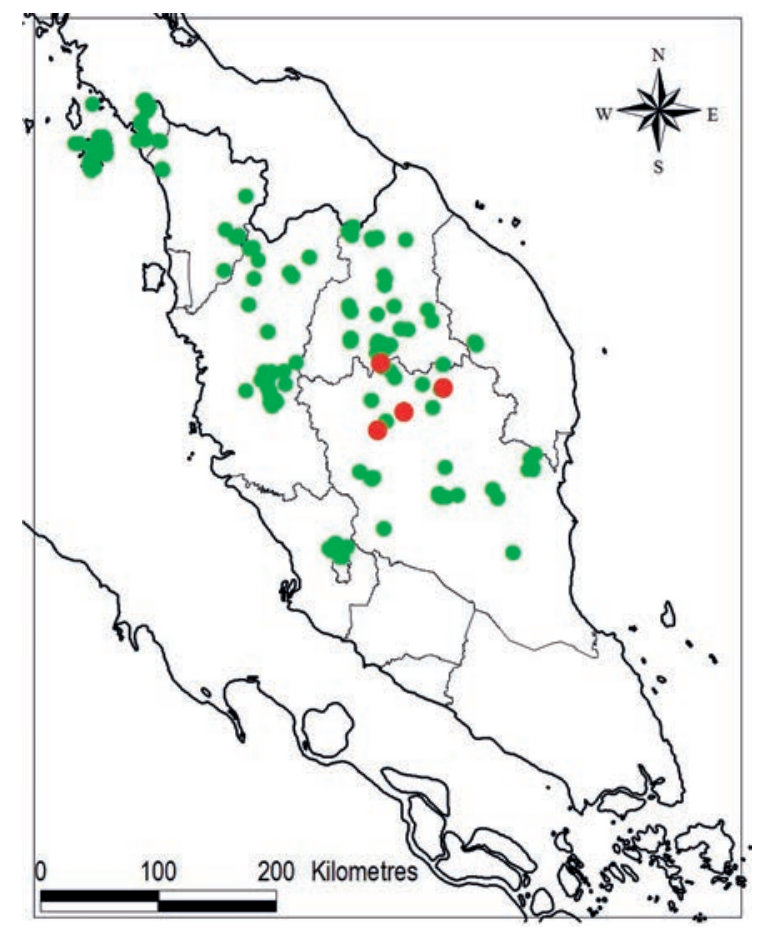

Fig. 3 Distribution of Spelaeanthus chinii indicated by red dots. The green dots indicate all the limestone hills in Peninsular Malaysia.

\section{CONCLUSION}

Using Gesneriaceae as a case study shows that to conserve maximum biodiversity it is necessary not only to select hills with a diverse representative flora of each of the three provinces but also to select all hills that harbour narrowly endemic species. The presence of narrowly endemic species would qualify a limestone hill as an Important Plant Area. However, although under the Malaysia National Strategy for Plant Conservation Target 6 of Conserving Plant Diversity, Malaysia has pledged to conserve $50 \%$ of IPAs (Saw et al., 2009) the protocol to designate, legalise and manage IPAs has yet to be developed. Nor does the status of limestone hills as Environmentally Sensitive Areas prevent them being used for other purposes as was witnessed recently at Batu Caves.

An urgent first step is the need to build a database of all the narrowly endemic species or those that are currently most threatened (Kiew et al., 2017). Like MyBIS: Malaysia Biodiversity Information System (www.mybis.gov.my), this database needs to be accessible online and well publicised so that it is readily available to decision makers and can be accessed when companies apply for quarry licences. At present authorities have no independent source of information available and often end up relying on the Environmental Impact Assessment that is paid for and prepared by the cement company. 
There is no doubt that the limestone flora is a particularly vulnerable vegetation type. In situ conservation is to be preferred because it preserves not only species but the entire highly specialised ecosystem. Further, extinction threatens narrowly endemic species because there is no mechanism for plant rescue with the establishment of a permanent secure place in Malaysia for ex situ conservation.

Even though the limestone flora of Peninsular Malaysia is relatively well known, detailed surveys of IPAs are still needed, as illustrated by the recent survey of Gunung Kanthan that revealed three new species (Tan et al., 2014) and of Bukit Chiku where a new species of balsam was discovered (Kiew, 2016). Clearly there is still much to be learned.

\section{ACKNOWLEDGEMENTS}

This study was funded by the Ministry of Science, Technology and Innovation, Malaysia (MOSTI) under the Flora of Peninsular Malaysia project (01-04-01-000 Khas) and Documentation \& Inventory of Flora of Malaysia project based at the Forest Research Institute Malaysia. The corresponding author thanks the 10th Flora Malesiana Symposium Grant and Training Committee and the Forest Research Institute Malaysia for the training grant and also gives special thanks to Dr Peter Wilkie for his support and encouragement.

\section{REFERENCES}

ASHTON, P.S. (1992). Plant conservation in the Malaysian region. In: YAP, S.K. \& LEE, S.W. (eds) In Harmony with Nature: Proceedings of the International Conference on Tropical Forests, 12-16 June 1990, Kuala Lumpur. Malaysian Nature Society, pp. 86-93.

CHIA, L.T. (1983). The lure of Bukit Takun. Malayan Naturalist, 37(2): 18-25.

CHIN, S.C. (1977). The limestone flora of Malaya 1, Gardens' Bulletin Singapore, 30: 165-219.

CORNER, E.J.H. (1960). The Malayan flora. In: PURCHON, R.D. (ed.) Proceedings of the Centenary and Bicentenary Congress of Biology, Singapore, 2-9 December 1958. University of Malaya Press, pp. 21-24.

DAVISON, G.W.H. (1991). A conservation assessment of limestone hills in the Kinta Valley. Final report - Malayan Nature Society Project 1/90, Malayan Nature Society.

DAVISON, G.W.H. \& KIEW, R. (1990). Survey of the flora and fauna of limestone hills in Kelantan with recommendations for conservation. WWF-Malaysia \& Malayan Nature Society, Kuala Lumpur (unpublished report).

HENDERSON, M.R. (1939). The flora of the limestone hills of the Malay Peninsula. Journal of the Malaysian Branch of the Royal Asiatic Society, 17: 13-87.

KIEW, R. (1985). The limestone flora of the Batu Luas area, Taman Negara. Malayan Naturalist, 38(3): 30-36.

KIEW, R. (1991). The limestone flora. In: KIEW, R. (ed.) The State of Nature Conservation in Malaysia. Malaysian Nature Society, Kuala Lumpur, pp. 42-50. 
KIEW, R. (1993). A flora survey of the limestone hills in Perlis with management recommendations. WWF-Malaysia, Kuala Lumpur (unpublished report).

KIEW, R. (1997). The Malaysian hills and limestone hills - threatened ecosystems. In: KIEW, R. (ed.) The State of the Environment in Malaysia. Consumer Association, Penang, pp. 66-73.

KIEW, R. (2005). Begonias of Peninsular Malaysia. Natural History Publications, Kota Kinabalu.

KIEW, R. (2014). Checklist of vascular plants from Batu Caves, Selangor, Malaysia. Check List 10(6): 1420-1429.

KIEW, R. (2016). Impatiens (Balsaminaceae) from karst limestone in Kelantan, Malaysia, including three new species. Gardens' Bulletin Singapore, 68(2): 225-238.

KIEW, R., CHUNG, R.C.K., SAW, L.G. \& SOEPADMO, E. (2010). Seed plant families in Peninsular Malaysia. Flora of Peninsular Malaysia 2(1): 3-15.

KIEW, R., RAFIDAH, A.R., ONG, P.T. \& UMMUL-NAZRAH, A.R. (2017). Limestone treasures: Rare plants in Peninsular Malaysia - What they are, where they grow and how to conserve them? Malaysian Naturalist, 71(1): 32-41.

KIEW, R., TAN, J.P.C., KAMARUDIN, S., YONG, K.T. \& IMIN, K. (2014). The uncertain future for the plants of Gunung Kanthan, Perak, Malaysia. Cave and Karst Science, 41(3): $120-128$.

PRICE, L. (2014). Caves and Karst of Peninsular Malaysia: A Register (2nd edn). Berliner Höhlenkundliche Berichte, vol. 54. Speläoclub, Berlin.

RAFIDAH, A.R., KIEW, R., IMIN, K. \& ROSDI, M. (2009). Ornithoboea flexuosa, a rare Gesneriad restricted to the limestone in Kedah. Conservation Malaysia Bulletin, 12: 5-6.

RAFIDAH, A.R., KIEW, R. \& MOHD. HAIRUL, M.A. (2010). Rare monotypic limestone genera in Pahang and Kelantan. Conservation Malaysia, 11: 5-6.

RAFIDAH, A.R. \& TAN, J.P.C. (2012). Paraboea bakeri. Flora of Peninsular Malaysia Online Newsletter, 108(12). Forest Research Institute Malaysia.

SAW, L.G., CHUA, L.S.L. \& ABDUL RAHIM, N. (2009). Malaysia National Strategy for Plant Conservation. Ministry of Natural Resources and Environment and Forest Research Institute Malaysia.

TAN, J.P.C., KIEW, R., SAW, L.G. \& UMMUL-NAZRAH, A.R. (2014). Three new species from Gunung Kanthan, a limestone tower karst in Perak, Malaysia. Phytotaxa 177(3): 146-154.

WHITMORE, T.C. (1975). Tropical Rain Forests of the Far East. Oxford University Press, Oxford.

WONG, K.M. (1998). Patterns of plant endemism and rarity in Borneo and the Malay Peninsula. In: PENG, C.-I. \& LOWRY, P.P. (eds) Rare, Threatened and Endangered Floras of Asia and the Pacific Rim. Academia Sinica Monograph Series, 16: 139-169. 